Section Editor

Robert C. Griggs, MD
WriteClick: Editor's Choice
Editors' Note: In their article "Cognitive outcome of patients with classic infantile Pompe disease receiving enzyme therapy," Ebbink et al. reported data consistent with Drs. Spiridigliozzi et al.'s findings that CNS glycogen does not significantly impair cognitive function through the middle childhood years but may be related to delayed processing speed. Drs. Walters et al. report the results of their investigation into possible etiologies behind chocolate consumption lowering stroke risk.

Megan Alcauskas, MD, and Robert C. Griggs, MD

\section{COGNITIVE OUTCOME OF PATIENTS WITH CLASSIC INFANTILE POMPE DISEASE RECEIVING ENZYME THERAPY}

Gail A. Spiridigliozzi, James H. Heller, Priya S. Kishnani, Durham, NC: We would like to inquire whether glycogen impairs cognitive function. In addition, since enzyme replacement therapy (ERT) does not cross the blood-brain barrier, does cognitive function decline over time? The data of Ebbink et al. ${ }^{1}$ suggest that glycogen in the CNS does not significantly impair cognitive function. This finding is consistent with an earlier report of 13 infants with infantile Pompe who responded positively to the first year of ERT and showed stable cognitive function at the lower end of the normal range. ${ }^{2}$ Additionally, stable function was reported within the lower end of the normal range for 7 children treated with long-term ERT for 6.75 years, on average. ${ }^{3}$ Scores on a standardized measure of adaptive functioning, negatively affected by motor performance, were below IQ scores. Both research teams identified a particular weakness in processing speed and the need for developmental and educational support services, longterm cognitive surveillance, and neuroimaging studies.

Author Response: Ans T. Van der Ploeg, B.J. Ebbink, F.K. Aarsen, C.M. van Gelder, J.M.P. Van den Hout, Rotterdam, the Netherlands: Our study ${ }^{1}$ confirmed Spiridigliozzi et al.'s,3 findings of normal or mildly delayed IQ scores in children with classic infantile Pompe disease treated with ERT. This is important because ERT cannot cross the blood-brain barrier. The longest follow-up reported by Spiridigliozzi et al. ${ }^{3}$ was 9 years and 11 months; ours was 12 years and 3 months.
Although Spiridigliozzi et al. ${ }^{2}$ found a correlation between cognitive and motor development, test limitations prevented them from determining whether lower cognition was caused by motor disabilities or weak cognition. Our more suitable nonmotor intelligence tests of 2 tetraplegic teenagers revealed the influence of severe motor disabilities on developmental scores. These teenagers previously had the lowest possible mental development scores during their first 4 years, but now scored normal or mildly delayed.

Similar to the findings of Spiridigliozzi et al., ${ }^{2}$ we also found delayed processing speed. Conceivably, these delays are explained by white matter changes like those on the MRIs we reported.

Although mild delays may develop over time, infantile Pompe disease differs substantially from other lysosomal storage diseases where progressive storage in the CNS and profound mental retardation occur at an early age.

\section{(C) 2013 American Academy of Neurology}

1. Ebbink BJ, Aarsen FK, van Gelder CM, et al. Cognitive outcome of patients with classic infantile Pompe disease receiving enzyme therapy. Neurology 2012;78:1512-1518.

2. Spiridigliozzi GA, Heller JH, Case LE, Jones HN, Kishnani PS. Early cognitive development in children with infantile Pompe disease. Mol Genet Metab 2012;105:428-432.

3. Spiridigliozzi GA, Heller JH, Kishnani PS. Cognitive and adaptive functioning of children with infantile Pompe disease treated with enzyme replacement therapy: long-term follow-up. Am J Med Genet C Semin Med Genet 2012; 160:22-29.

\section{CHOCOLATE CONSUMPTION AND RISK OF STROKE: A PROSPECTIVE COHORT OF MEN AND META-ANALYSIS}

Matthew R. Walters, Catherine Williamson, Kathryn Lunn, Alison Munteanu, Glasgow, UK:

Larsson et al. ${ }^{1}$ investigated the association between chocolate consumption and risk of stroke in men, concluding that moderate chocolate consumption may lower the risk of stroke. We performed a prospective mechanistic study that may suggest a potential mechanism for this observation.

We investigated the acute effects of a bar $(100 \mathrm{~g})$ of dark or milk chocolate upon cerebrovascular reactivity in healthy volunteers. The flavanol content of the dark and milk chocolate was $104 \mathrm{mg}$ and $32 \mathrm{mg}$ of epicatechin, 
respectively. Using a randomized double-blind crossover design, cerebral vasomotor reactivity was measured by transcranial Doppler ultrasound and calculated using breath-hold index (BHI).

Twenty-four fasted, healthy volunteers on no regular medication (12 female, 12 male, mean age 23.2 years [SD 3.29]) attended twice, each study visit at least 24 hours apart. Chocolate caused a significant change in BHI by -0.06 units 90 minutes after chocolate ingestion (BHI pre 1.3 [SD 0.16]; BHI post 1.24 [SD 0.14]; $p=0.015, \mathrm{n}=48)$. Dark chocolate caused a significant reduction in $\mathrm{BHI}$ from baseline by -0.07 units (SD 0.17; $p=0.05, \mathrm{n}=24$ ), though the change in BHI between dark and milk chocolate was not significant (BHI dark -0.07 [SD 0.17]; BHI milk -0.04 [SD 0.13]; $p=0.431, \mathrm{n}=24$ ). No differences in blood sugar, heart rate, or blood pressure were apparent between groups.

Acute ingestion of chocolate was associated with a measurable change in cerebral vasomotor reactivity. Regular consumption of cocoa polyphenols has been shown to reduce the risk of stroke, and antioxidant, antiplatelet, and anti-inflammatory effects, together with effects on lipid profile, have all been proposed as potential mediators of the effect. ${ }^{2}$

Our data suggest that chocolate consumption is associated with an acute change in cerebral vasomotor reactivity, independent of metabolic and hemodynamic parameters. This acute effect may contribute to the observed relationship between long-term chocolate consumption and stroke risk, and is worthy of further investigation.

(C) 2013 American Academy of Neurology

1. Larsson SC, Virtamo J, Wolk A. Chocolate consumption and risk of stroke: a prospective cohort of men and metaanalysis. Neurology 2012;79:1223-1229.

2. Corti R, Flammer AJ, Hollenberg NK, Luscher TF. Cocoa and cardiovascular health. Circulation 2009;119: $1433-1441$.

\section{CORRECTION}

Novel brain expression of CIC-1 chloride channels and enrichment of CLCN1 variants in epilepsy

In the article "Novel brain expression of $\mathrm{ClC}-1$ chloride channels and enrichment of CLCN1 variants in epilepsy" by T.T. Chen et al., which was published ahead of print on February 13, 2013, reference 8 should not have been listed, as it was retracted in 2009. A corrected version of the article, with this reference removed, is published in Neurology ${ }^{\circledR} 2013 ; 80$ : 1078-1085. The authors regret the error. 


\section{Neurology}

\section{Chocolate consumption and risk of stroke: A prospective cohort of men and meta-analysis}

Matthew R. Walters, Catherine Williamson, Kathryn Lunn, et al.

Neurology 2013;80;1173-1174

DOI 10.1212/01.wnl.0000428365.81656.e0

This information is current as of March 18, 2013

\section{Updated Information \&} Services

References

Permissions \& Licensing

Reprints including high resolution figures, can be found at: http://n.neurology.org/content/80/12/1173.2.full

This article cites 2 articles, 2 of which you can access for free at: http://n.neurology.org/content/80/12/1173.2.full\#ref-list-1

Information about reproducing this article in parts (figures,tables) or in its entirety can be found online at:

http://www.neurology.org/about/about_the_journal\#permissions

Information about ordering reprints can be found online: http://n.neurology.org/subscribers/advertise

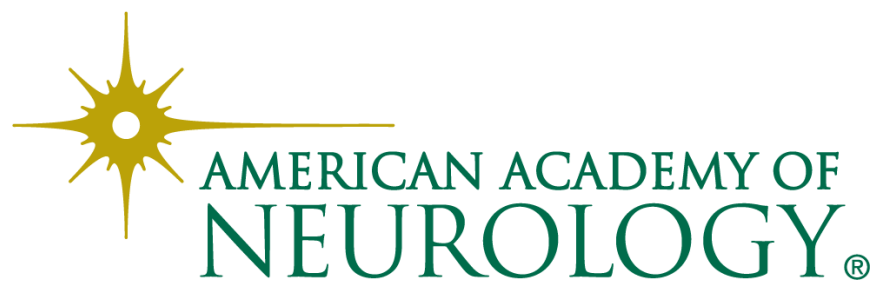

